endorsed the nuclear adventure. "This is a political and defence matter on which our academy cannot take any stand," says Srinivasan Varadarajan, president of the Indian National Science Academy in New Delhi.

Varadarajan also doubts that the latest scientific feat is likely to create a climate for more funding for scientific research in general. "More money will certainly start flowing to defence and atomic research, but these are areas that are already getting the biggest share of our budget."

Sanctions by the United States and other countries would admittedly hurt several health and development projects. The effects of the tests on India's science establishments have yet to be gauged, but no one seems particularly worried. "Sanctions are welcome," says Mashelkar, pointing out that India "seems to excel precisely in those areas in which technology is denied".

The Indian Space Research Organization, which has learnt to live with a variety of sanctions in the past, says "sanctions will pinch, but not hurt". But some defence projects, such as the light combat aircraft which critically depends on a flight control system from Lockheed Martin of the United States, may be in jeopardy.

Work on the main battle tank, which uses German engines, and the advanced light helicopter, which requires components from the United States, may also be affected. But Kalam says denials will help spur selfreliance. "No one can throttle us."

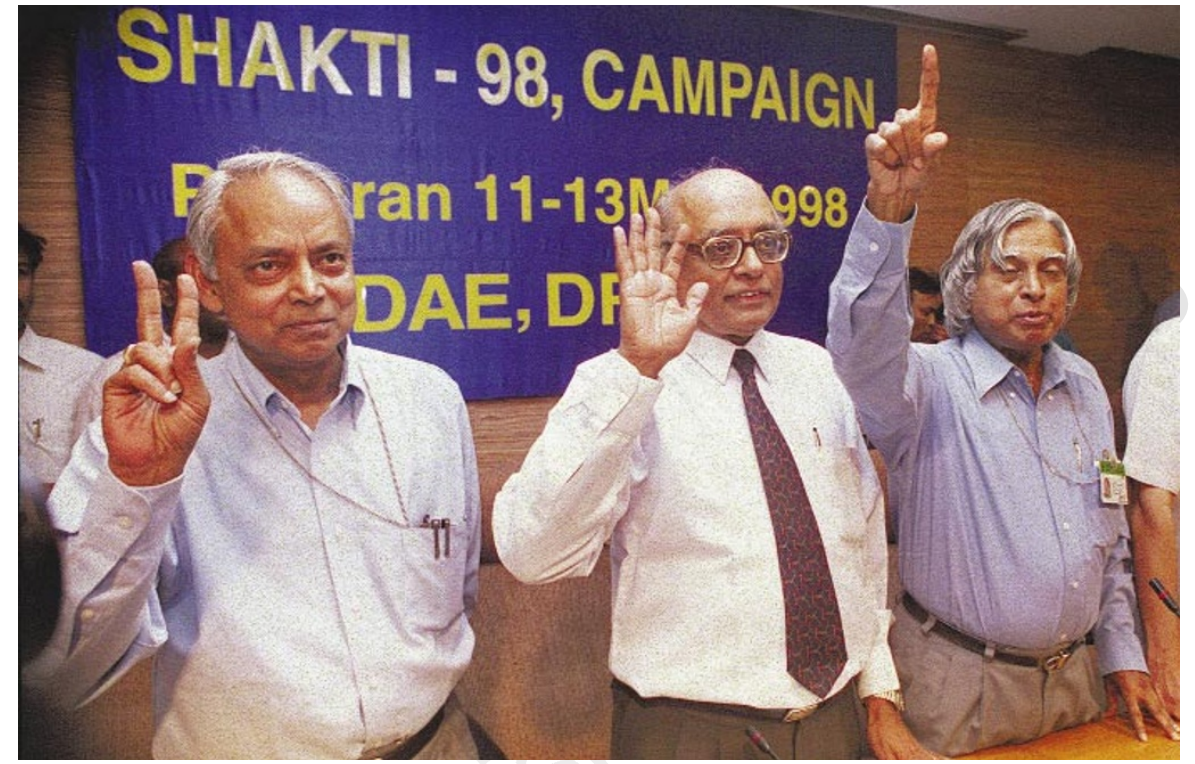

Approval from K. Santhanam, R. Chidambaram and Abdul Kalam of the atomic energy establishment.

Gyanendra Nath, however, an adviser in the international division of the Ministry of Science and Technology, says that repercussions in many collaborative projects "are going to be serious". He says cancellation of DM300 million (US\$168.3 million) in grants to India will jeopardize a two-year IndoGerman programme on nanotechnology.

Germany has also been funding research in superconductivity at the National Physical Laboratory in New Delhi and is a major donor (\$20 million) to the Indian Institute of Technology in Madras. With Japan cutting off its aid, the Indo-Japanese project at the SPring-8 synchrotron may close down, says Nath.

Since the winding up of the India-US fund in January this year, there has been no major US-funded project in India, and officials say the United States cannot afford to take actions that will hurt collaborative projects in weather or vaccine research "since they [the United States] will be the losers."

K.S.Jayaraman

\title{
Disappointment as New Zealand's budget gives science 'inflation'
}

[CANBERRA] Research gained a small increase in the budget of the New Zealand government, delivered last week. But the increase received a mixed reception, and New Zealand science seems to be following other downward trends evident in the Australian budget revealed two days earlier (see Nature 393, 101; 1998).

Maurice Williamson, New Zealand's minister for research, science and technology, announced that NZ\$10 million (US\$5.34 million) more would be allocated to research in all portfolios, bringing the 'science envelope' to a total of NZ\$600 million, and representing an increase roughly in line with expected inflation.

Of this extra money, the Public Good Science Fund (PGSF), administered by the Foundation for Research Science and Technology, will receive another NZ\$9 million, bringing its funding to NZ\$317.3 million for 1998-99. The remaining NZ\$1 million is directed to "non-specific output funding" for nine government-owned Crown Research Institutes.

Science leaders have praised Williamson for holding the line against reported cabinet opposition and keeping spending on research constant in real terms. Yet there is a marked shortfall from the extra NZ\$25 million that Williamson had earlier stated was needed to keep up with the growth in gross domestic product (GDP) (see Nature 391, 426; 1998).

In a statement, Williamson claimed that the increase in dollars is "a continuation of the government's commitment to increase public investment to 0.8 per cent of GDP by 2010". But observers predict that the national expenditure on research and development relative to GDP will slip below the last stated New Zealand figure of 0.52 for 1995-96.

The PGSF is the principal source of competitive funding for Crown Research Institutes, as well as for projects by researchers in the country's seven universities. An extra NZ\$7.7 million is being directed by Williamson to 17 areas of the fund in proportions largely unchanged from the past two years.

The 18th area, the Health Research Council, will receive an extra NZ\$1.5 million, taking its total to NZ\$33.2 million. But this research council has also been moved from marginal to full-cost funding of research grants within three years, and the result is likely to be a fall in the size of grants.
The Marsden Fund for competitive grants in basic research, run by the Royal Society of New Zealand, will remain at last year's level of NZ\$22 million, and the government has dropped its own target of increasing the fund to 10 per cent of the PGSF. The president of the academy, George Petersen, speaking in a personal capacity, "particularly regrets" this decision.

Although acknowledging fiscal restraints, he says it "will require massive increases to bring spending on basic research back on track. The budget sends very poor signals to the scientific community and the government is clearly putting other priorities ahead of science."

Before the publication of a government white paper detailing decisions on a review of higher education (see Nature 392, 320; 1998), the education minister, Wyatt Creech, announced a massive change in the university funding system to a new taxpayerfunded 'Universal Tertiary Tuition Allowance'. While vice-chancellors welcome the change, staff and students are violently opposing universities being driven by students' choices through portable, personal 'vouchers'.

Peter Pockley 